\title{
Article \\ Critical Review of Public Policies for the Rehabilitation of Housing Stock: The Case of Barcelona
}

\author{
Angel Uzqueda ${ }^{1}$, Pilar Garcia-Almirall ${ }^{2} \mathbb{D}$, Còssima Cornadó ${ }^{2, *(D)}$ and Sara Vima-Grau ${ }^{2}$ (D) \\ 1 Municipal Institute of Housing and Renovation, Ajuntament de Barcelona, 08003 Barcelona, Spain; \\ auzqueda@bcn.cat \\ 2 Architectural Technology Department, Universitat Politècnica de Catalunya-Barcelona Tech, \\ 08028 Barcelona, Spain; pilar.garcia-almirall@upc.edu (P.G.-A.); sara.vima@upc.edu (S.V.-G.) \\ * Correspondence: cossima.cornado@upc.edu
}

Citation: Uzqueda, A.;

Garcia-Almirall, P.; Cornadó, C.;

Vima-Grau, S. Critical Review of

Public Policies for the Rehabilitation

of Housing Stock: The Case of

Barcelona. Buildings 2021, 11, 108.

https://doi.org/10.3390/

buildings11030108

Academic Editor: Ana Silva

Received: 8 February 2021

Accepted: 4 March 2021

Published: 9 March 2021

Publisher's Note: MDPI stays neutral with regard to jurisdictional claims in published maps and institutional affiliations.

Copyright: (c) 2021 by the authors. Licensee MDPI, Basel, Switzerland. This article is an open access article distributed under the terms and conditions of the Creative Commons Attribution (CC BY) license (https:// creativecommons.org/licenses/by/ $4.0 /)$

\begin{abstract}
This article reviews rehabilitation programs in Barcelona, focusing on aspects such as the intervention model, actual public investment, and results. Programs of this type are not exclusive to Barcelona; however, similar examples can be found in other European cities, especially where European Union (EU) funding is present. After analyzing these models, we reached a series of general conclusions that may be of interest. Thus, an eminently practical and reflective analysis is presented, aimed at technicians and those responsible for the design of intervention policies in urban regeneration. Rehabilitation programs are increasingly focused on vulnerable settings, and in this context, the participation and service function of public administrations are particularly relevant. The general model for rehabilitation subsidies rarely takes into account the specific characteristics of disadvantaged urban settings, as the article will show. After analyzing the different policies presented in this research, we identified two essential requirements: detailed knowledge of the affected neighborhood, and ongoing evaluation of the development of programs-beyond simple management indicators-so negative effects can be corrected in time such as gentrification, real estate speculation, and other by-products that the intervention itself can promote. This study confirms that not all public investments have the expected results.
\end{abstract}

Keywords: public rehabilitation policies; housing rehabilitation; urban regeneration

\section{Introduction}

We hope to determine whether existing public models for urban rehabilitation work in cities, particularly in a context of global and systemic crisis, as well as whether it is possible to contribute from an empirical evaluation, in the formulation of intervention proposals, and assess their limitations. Moreover, we hope to determine how these policies can be adapted to deal with the present circumstances and a wide range of complicated urban variables, such as economics, employment, education, mobility, safety, administration, health, and participation.

Most work concerning rehabilitation and maintenance of buildings is by the initiative of the owners, who must also provide most of the funding. However, public administrations have sought to drive rehabilitation work and fill in certain gaps in keeping with their role as a public service. Nonetheless, as we will see, their efficiency and efficacy in doing so have proven somewhat limited.

This article analyses public intervention policies applied in Barcelona that may serve as an example for other cities in similar contexts. As we will see, these initiatives have different effects in the city center than they do in outlying areas. The capital gains generated by public interventions in central neighborhoods attract the intervention of real estate companies. Regardless of whether wealthier social classes are also drawn to the area, this often spurs illicit attempts at profiteering. Meanwhile, in outlying neighborhoods, urban 
investment does not generate significant capital gains; however, it does improve the quality of life and attract members of the working class.

It is also worth noting that the current circumstances have no precedent. In Europe, an unparalleled series of public investments are being consolidated: the Next Generation European Union (EU) program. This program is expected to include $€ 1.8$ billion in subsidies from 2021 to 2027 [1]. In this context, we must look at the progress of policies for public intervention in cities, particularly in the rehabilitation and regeneration of the residential fabric. It is also essential that we determine the results of the rehabilitation initiatives that have taken place so far, so that we can organize any new interventions in the best way possible. This investigation analyses different policies and programs for public investment, such as:

- The general program for subsidizing the rehabilitation of residential buildings in Barcelona for the 2010-2018 period. This program was launched in 1988 and is still active [2].

- Renewal of the historic city center, or "Ciutat Vella". Developed as a master plan from 1988 to $2002[3,4]$.

- A series of neighborhood programs for primarily urban interventions in disadvantaged areas, developed from 2004 to 2010 [5].

- The Pla de barris or "Neighborhood Plan," designed as an eminently social program based on citizen participation and empowerment, in place since 2016 [6].

This work aims to carry out a critical analysis, in practical matters, of the public management of the urban rehabilitation and regeneration programs carried out in Barcelona in recent times. The research is based on the debate of public management, in relation to intervention programs and their implications for citizens. Thus, a contribution is made that can serve to improve governance instruments, from the evaluation of actual urban plans.

\section{Conceptual Framework and Methodology}

The new public management model, widely introduced in administrative management from a business perspective [7], responds inadequately to the situation generated since the economic crisis of 2007. In this context of systemic crisis, currently aggravated by a health emergency, new models based on governance are explored [8]. Although an alternative model has not been consolidated, different initiatives coexist, be they continuity, transition, or new innovative management models that are emerging [9]. Public action strategies require continuous availability of resources and a model of intervention and governance (capacity to decide) related to the objectives. Social disaffection towards public management advocates the need for new proposals from a democratic approach [10] with an impartial, transparent, and participatory administration.

Governance is consolidated as one of the fundamental aspects for the development of intervention policies in the city in which civil society acquires relevance, in a context of democratic organization. In this sense, it is of special importance in the development of urban policies, in addition to transparency and participation, the co-responsibility of civil organizations [11]. In the design of new programs, the empirical knowledge of other similar practices has a reference value that is usually considered, at least, in the context of European cities.

The evaluation of urban interventions presented in this article is supported by an analytical methodology. It is intended to obtain magnitudes that can be extrapolated and, likewise, provide objective results that allow a critical study of the values obtained. Although a quantitative analysis prevails, in addition, different qualitative aspects are contemplated that complement the evaluation, with the intention of integrating both approaches, following a hybrid methodology [12]. In this way, the approach to the characteristics and objectives of the programs contextualizes and complements their knowledge.

Each of the four programs analyzed-the general program for subsidizing the rehabilitation of residential buildings, the renewal plan of the historic city center, the neighborhood plans, and the Pla de barris-presents the same structure in the paper: 
- Explanation of each model and its characteristics in order to contextualize it in reference to other cities.

- Contribution of management data and execution times of each program. In this way, the volume of resources used and the results obtained in the validity periods of each program can be contextualized.

- Evaluation after a sufficient period of time to be able to assess the effects that the intervention has produced. At this point, it is possible to carry out a critical analysis and draw conclusions that may be useful for the design and governance of other programs.

\section{Contextualization}

In relation to housing policies, beyond the broad institutional recognition, a different reality is observed: residential exclusion in Spain affects $24 \%$ of the population [13]. The welfare state has not conveniently addressed the problem. In Spain, and in general in southern Europe, they have opted for the purchase of housing. On the contrary, in northern and central European countries, affordable housing models have been developed from a cooperative conception. The European average living in home ownership represents $70 \%$, in Spain 76.2\% while in Germany 51.1\% [14].

Likewise, there is a neglect in the creation of public housing for social rent, which in southern cities, such as Barcelona is at a minimum of $2 \%$, as opposed to $48 \%$ in Amsterdam or $30.2 \%$ in Berlin. The challenge of Barcelona's public housing policy is to change the model, to converge with the good practices of the European Union, since, for the moment, the scarce stock of social housing cannot offset the high values of the rental market [15].

Mercantilism in housing has gained ground in the face of social need. Cities are home to large pockets of poverty and marginalization, especially in neighborhoods susceptible to real estate transformation processes in which the population suffers especially severely from the sale of housing [16]. Barcelona has not been an exception, and it is still prone to gentrification today. The effort of family income in housing stands at $53 \%$, and $15.4 \%$ of families are below the poverty line [17].

From an evolutionary and syncretic vision of urban intervention policies in Barcelona, a transition is observed from the so-called Barcelona model to plans based on citizenship, quality of life, and residential vulnerability. If the beginning of democracy meant a qualitative leap in the intervention on the city, with the support of the quality of the technicians, in the Olympic times a different approach was imposed, driven by investment interests and by the search for milestones, such as the Olympic Games of 1992 or the Forum of Cultures in 2004.

The Barcelona model represented a standard of urban intervention supported by large neoliberal conjuncture projects and with the will to be exported, an urbanism of globalization [18]. The model favors the action of large real estate operators at the same time that it forces a greater involvement/dependence on public-private collaboration that reduces the capacity of control by the administration and has caused a distance between politics, urban planning, and citizenship.

Reasonably, there has been a transition towards interventions focused on social and environmental criteria. Although housing focuses the intervention, due to the effects of the 2007 crisis, introducing innovative criteria in the management of evictions and the creation of affordable housing $[19,20]$, a holistic intervention strategy is also developed in peripheral and underprivileged neighborhoods: "Pla de Barris" [21]. Moreover, with the aim of providing a model for the transformation of public space, the "Superilles" are being developed in central sectors: projects based on the reversion of public space to citizens [22]. These three levels of intervention place the citizen at the forefront of urban public policies. In this scenario, the maintenance of residential buildings is precarious and, consequently, rehabilitation policies are necessary, especially in vulnerable residential environments [23]. 


\section{A Consensus-Based Model}

As a result of evolution and collective knowledge, we now have a network of references that can guide public policies for urban renewal. The United Nations (UN) 2030 Agenda and Urbana Habitat III, the European Union Toledo Declaration, the Riga Declaration, and many other national and municipal directives all point towards the same goal: the development of urban policies that take a wide range of factors into account and focus on vulnerable areas [24]. All contain similar guiding principles for urban rehabilitation and regeneration. They all serve as a coherent guide that we believe should be considered when planning urban renewal.

In sustainable urban development, climate-related issues are particularly important. The energy efficiency of our cities' residential fabric is still quite low, and, as a result, greenhouse gas emissions are still too high. According to data from the Spanish Ministry for the Ecological Transition and the Demographic Challenge [25,26], nearly $58 \%$ of buildings in Spain were built before the first energy efficiency requirements came into effect. Moreover, $61 \%$ of greenhouse gas emissions are attributed to residential buildings. These circumstances place our cities in urgent need of adaptation.

In essence, we need to promote comprehensive plans and urban renewal in a context of sustainable urban development, particularly in underprivileged neighborhoods. We need to "make cities and human settlements inclusive, safe, resilient, and sustainable" [27].

\section{Strategies for Public Rehabilitation in Barcelona}

Just as in other large cities, we can divide the Barcelona City Council's interventions in rehabilitation work into two main categories: first, a program for subsidizing rehabilitation work; second, projects in the affected areas that involve a holistic treatment of urban intervention. The different rehabilitation strategies used are presented and analyzed below.

\subsection{Public Subsidies for the Rehabilitation of Residential Buildings}

Public subsidies for rehabilitating residential buildings seek to fund renewal with direct, non-refundable economic aid. With some variations in the aid provided, this model is applied throughout Europe [28], including cities in Spain. In Barcelona, these subsidies cover $20-50 \%$ of the cost of the work-except for exceptional circumstances-and are basically paid with municipal funds [2]. They are based on national laws, with annual calls for applications managed by city council. Homeowners request these subsidies at housing offices before starting the renovation. Once work is completed and technical and administrative compliance are ensured, the aid is granted.

The first decree regulating these type of subsidies was published in 1988 [29]. New decrees have included very limited changes. One of their main advantages has been that they are flexible enough to adapt to any sort of rehabilitation work. With its strengths and weaknesses, this program remains applicable in Spain [30]. Few differences exist between the programs of this type in different European countries.

With support from this model, intervention programs have been developed across Barcelona. Some have impacted residents' quality of life, permitting initiatives such as the installation of elevators [31,32] despite the technical complexity and significant cost of placing them in buildings designed without this element in mind.

To promote the installation of new elevators and avoid administrative obstacles, an inter-administrative commission was created along with new urban plans that allow elevators to be installed on the outside of buildings. From 2010 to 2018, this accessibility initiative made up $40 \%$ of all programs completed in Barcelona with public subsidies $[33,34]$ (Figure 1). 

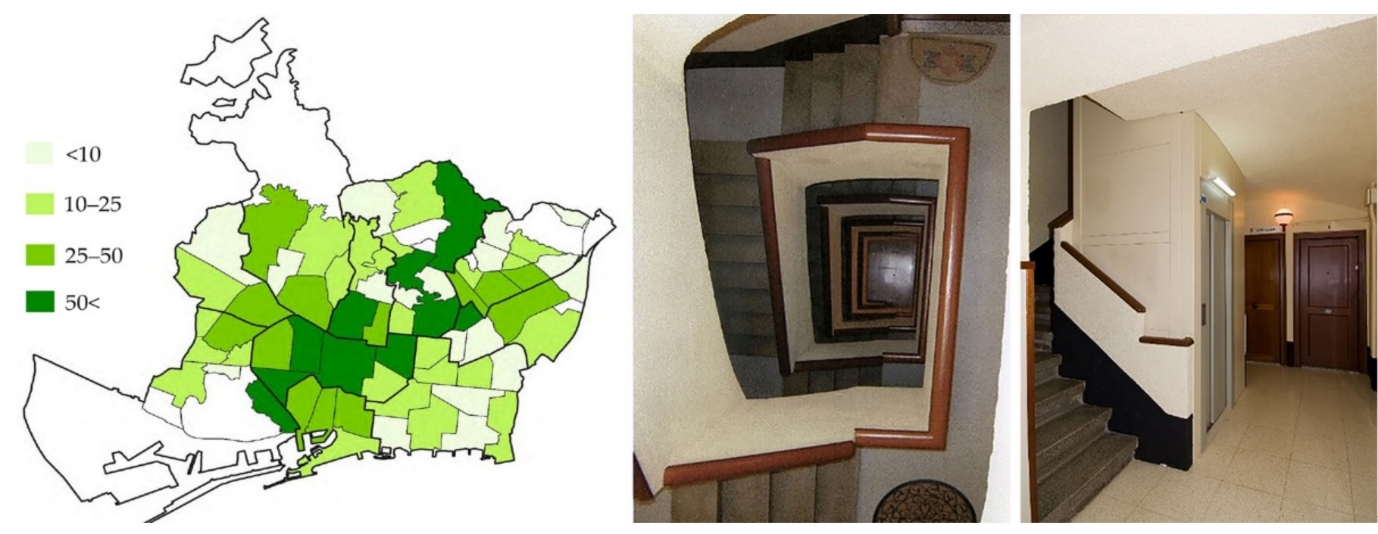

Figure 1. Map: accessibility interventions by neighborhood (2010-2018). Before and after pictures of the installation of a new elevator in the stairwell of a building with four apartments per floor. Source: Rehabilitation study [34].

In the evaluated period, the adaption of common spaces in communities of homeowners made up a large part of subsidized interventions (Table 1). Within these, critical interventions involving the structure and soundness of buildings made up $10 \%$, while simpler interventions, such as the renovation of façades, rooves, or utilities made up $70 \%[33,34]$.

Table 1. Subsidies in residential buildings, 2010-2018.

\begin{tabular}{ccc}
\hline Scope & Accessibility Programs & Total Programs \\
\hline Rehabilitation work & 1512 buildings & 3935 buildings \\
Homes benefitted & 32,238 homes & 85,125 homes \\
Total cost of interventions & $€ 107.75$ million & $€ 308.8$ million \\
\hline Source: rehabilitation study [34]. & &
\end{tabular}

Because it has been active since 1988 and because of the number of interventions it has funded-approximately 400 buildings a year-this program continues to be a point of reference with a huge impact on the city. One study on rehabilitation [34] shows that $80 \%$ of these subsidies have gone to communities of homeowners. Communities of homeowners in Barcelona are governed by the Civil Code of Catalonia. They are formed in buildings where each residence has a different owner. In keeping with the procedures set forth by the law, the community is responsible for any maintenance and rehabilitation work approved by a simple majority of homeowners. In total (Table 2), 8366 interventions-primarily involving façades and rooves-have been funded. It is important to keep in mind that a single building may have undergone different interventions by applying for multiple types of subsidies.

Table 2. Interventions subsidized from 2010-2018.

\begin{tabular}{ccccc}
\hline Intervention & $\begin{array}{c}\text { Horizontal } \\
\text { Property }\end{array}$ & $\begin{array}{c}\text { Vertical } \\
\text { Property }\end{array}$ & Total & Percentage \\
\hline Structural work & 679 & 128 & 807 & $10 \%$ \\
Non-structural work & 3439 & 875 & 4314 & $51 \%$ \\
Accessibility & 1401 & 289 & 1690 & $20 \%$ \\
Installations & 1150 & 405 & 1555 & $19 \%$ \\
TOTAL & 6669 & 1697 & 8366 & $100 \%$ \\
\hline
\end{tabular}

Although this model does follow technical criteria to a certain degree, it is mostly based on partial rehabilitations where the owners decide what elements to prioritize and when. The administration promotes certain interventions by providing greater subsidies for certain types of work. Neighborhoods with low disposable household income have received fewer subsidies for renovation (Figure 2); this is due to both difficult economic 
circumstances and difficulty managing subsidies, and it shows that a different model for intervention is required in underprivileged areas. To apply for the subsidy, owners are expected to present around 20 different documents; the internal administrative process they must navigate to be accepted is even more complex.

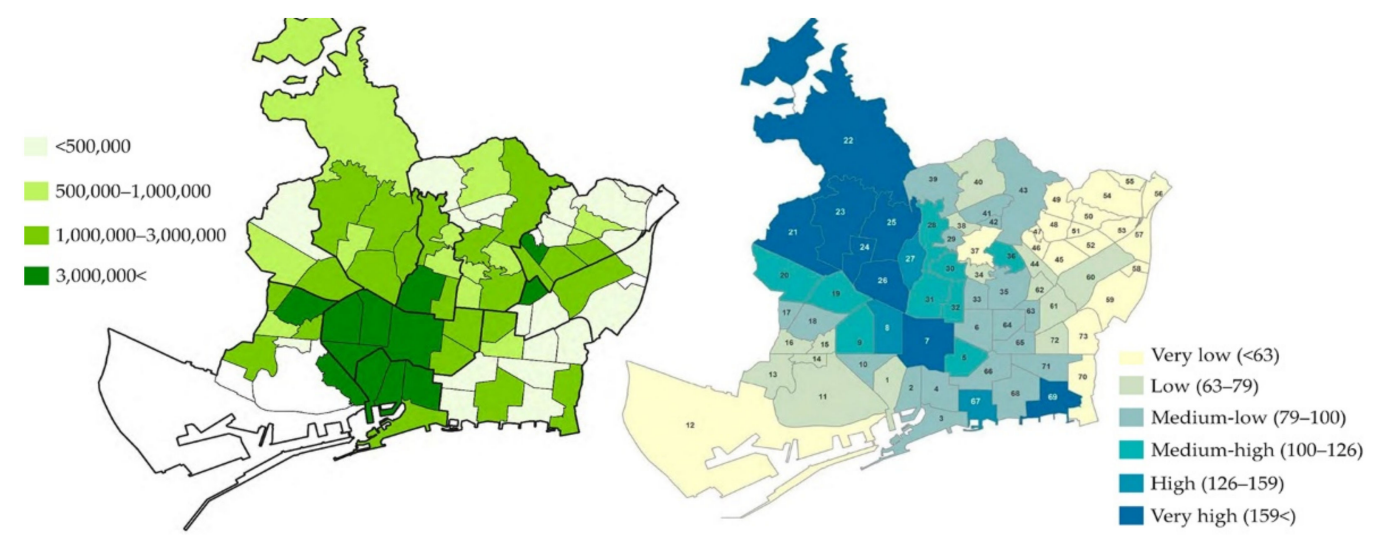

Figure 2. Subsidies granted in residential buildings, 2010-2018. Disposable household income.

Due to their general nature, these subsidies require no previous knowledge of the area. Most evaluations of this type of aid have focused only on management and geographic distribution. To correct this weakness, a second model was developed in certain areas of the city (see below). In this newer model, interventions are intended to be more holistic, with the incorporation of both social and urban circumstances. Moreover, specific management bodies are created to coordinate such interventions.

\subsection{The Ciutat Vella Integrated Rehabilitation Area}

The declaration of an Integrated Rehabilitation Area (Àrea de Rehabilitació Integral, or ARI) in 1986 marked the start of an intervention program for Ciutat Vella, Barcelona's historic center [35]. This ambitious master plan sought to reverse the ongoing degradation the area had experienced since the 1960s. Ciutat Vella was dealing with long-term abandonment made evident by the obsolescence and insufficiency of public spaces, the lack of public facilities, and the precarious state of the residential fabric. The area's population was in steep decline as delinquency, drug use and prostitution gained ground. The area's importance as the center of government; the historic value of its architecture and a closelyknit social fabric led to the start of a recovery program under the slogan "save downtown!" To guide and develop the plan, a public-private committee was created with neighborhood associations, the public administration, and a company responsible for management [35].

The new plan consisted of a series of strategic projects. The economic value of each was determined, and they were then organized chronologically. Investment commitments were also obtained from state, regional, and local governments, in keeping with strategies for developing different strategic projects (Figure 3).

As for the scope of the intervention, the office of the Integrated Rehabilitation Area earmarked $€ 1241$ million for public investment for the 1988-2002 period, a sum representative of both the area's needs and its potential. How it was spent showed a clear attempt to maintain the area's residential fabric and reverse its population loss: $21 \%$ was invested in housing, while $10 \%$ was invested in neighborhood amenities. There was also a clear investment in the area's role as a city center, with $38 \%$ dedicated to citywide amenities. To meet both objectives, public spaces and the associated service infrastructures were improved (Figure 3). 

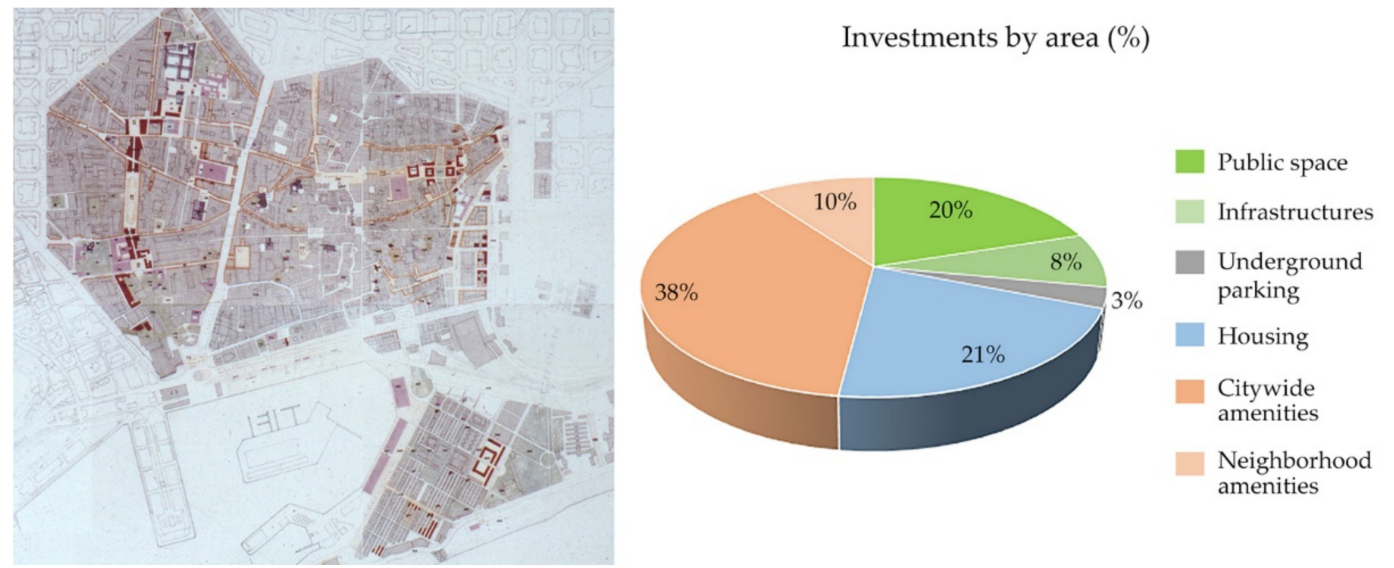

Figure 3. Map: Program of interventions in Ciutat Vella. Graph: Public investment in Ciutat Vella. Source: Àrea de Rehabilitació Integral (ARI) Ciutat Vella [35].

In this context, the Office for the Rehabilitation of Ciutat Vella was created to promote the rehabilitation of the private housing fabric and complete the public program. Rehabilitation work was based on national decrees and gained momentum as the program advanced, although it also received the ad hoc support of a joint commission with representatives from the national, regional, and local administrations. The total accumulated public investment in subsidies for the 1988-2002 period was $€ 32.88$ million, which included a private investment in rehabilitation of $€ 165.16$ million. (Figure 4).
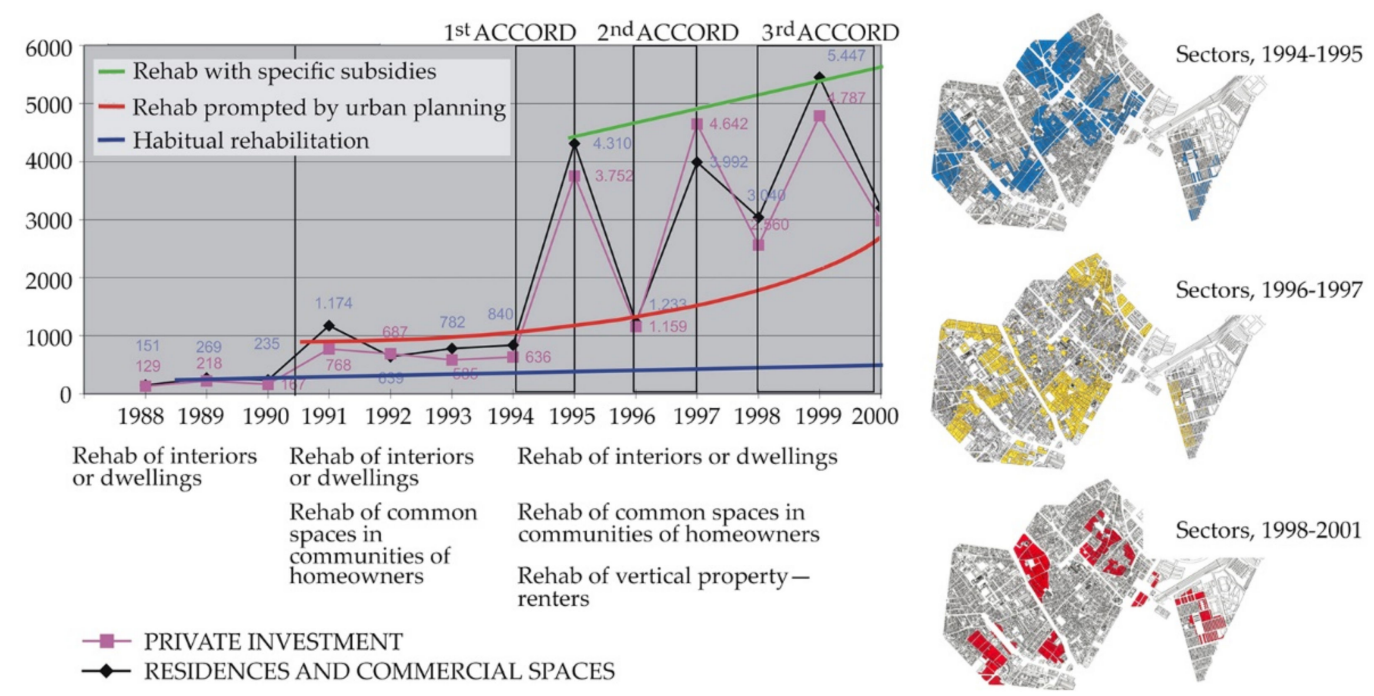

Figure 4. Evolution of publicly subsidized, private rehabilitations of homes in Ciutat Vella.

One intervention strategy, the definition of "preferential action sectors", led to a significant increase in rehabilitation work. In certain sectors and over two-year periods, the percentage of subsidies rose from $20 \%$ to $30 \%$. Using the resulting management data, it was determined that this strategy led to values that were double that of other sectors. The context of opportunity plays a key role in the promotion of rehabilitation work. By 2004, initial goals had been met, and the resulting changes were well-received by the real estate market. Population loss was halted, and the first signs of gentrification began to appear [36-38]. Social classes with greater resources began to return to the city center, initially occupying empty housing stock. There was also a notable rise in real-estate investment.

Although the goal of reversing the degradation of the city center has been achieved, there have also been negative effects due to profiteering. More and more residences are being used to house tourists. There has also been a rise in real estate mobbing, where 
residents are expelled so their homes can be sold for higher prices [39]. Finally, others have sought to benefit from marginality and overcrowding, renting spaces that do not fulfill minimal housing standards $[40,41]$. To correct the unwanted side effects of plans for urban renewal, we have found that ongoing evaluations are necessary. In fact, all such plans should include a monitoring system from the start.

One evaluation of the results of the rise in capital gains [42] shows that a sustained public investment of $€ 95$ million per year in Ciutat Vella led to a private investment of $€ 110$ million per year, and a final process of private capital gains of $€ 10.2$ million- $€ 14.4$ million per year. This intervention led to private gains of $€ 320$ million per year, well above the city average (Figure 5).
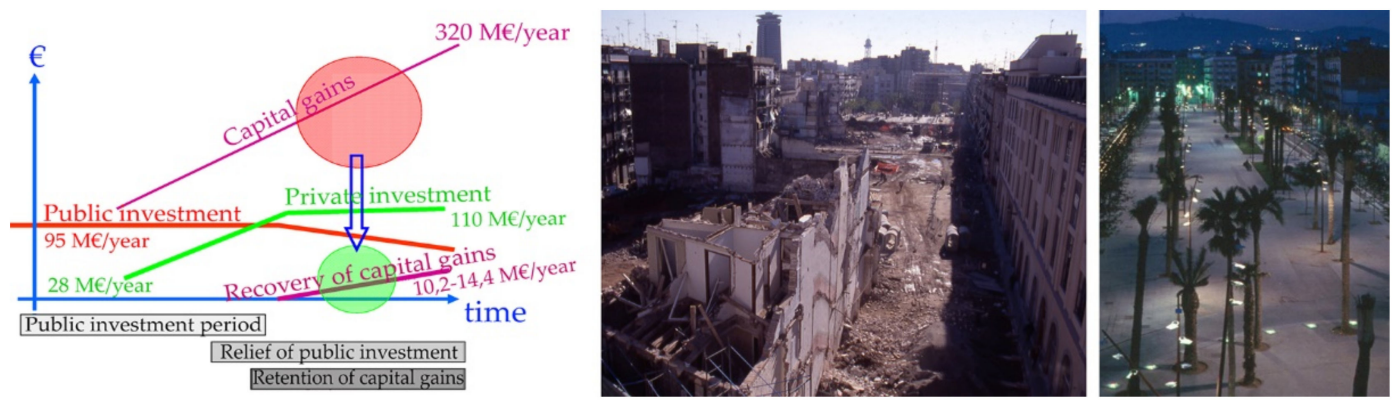

Figure 5. Graph: public investment and capital gains in Ciutat Vella. Images: the opening of the Rambla del Raval in Ciutat Vella, Barcelona. Source of images: opening of the Rambla del Raval. Integrated Rehabilitation Area of Ciutat Vella. Barcelona $[43,44]$.

\subsection{Programs for Neighborhood Intervention; the "Neighborhood Law"}

A determined initiative of the Government of Catalonia, "Llei 2/2004 de millora de barris, àrees urbanes i viles que requereixen una especial atenció" (Law 2/2004 for the improvement of neighborhoods, urban areas, and towns requiring special attention) [45], was passed to create comprehensive programs for renewing Catalonia's most disadvantaged neighborhoods. These neighborhood programs were developed through the initiative of town halls and were co-funded with equal contributions by the Catalan and municipal governments. All proposals were evaluated using a series of standardized indicators and could include a maximum investment of $€ 20$ million. Intervention was based on four main areas:

- Population loss and a lack of amenities and services;

- Demographic issues;

- Economic, social, or environmental issues;

- Social and urban deficits and local development issues.

Like the European Union's European Regional Development Fund (ERDF) programs, the law sought to design a coherent plan for urban renewal with well-defined projects involving eight main fields [45] (Figure 6).

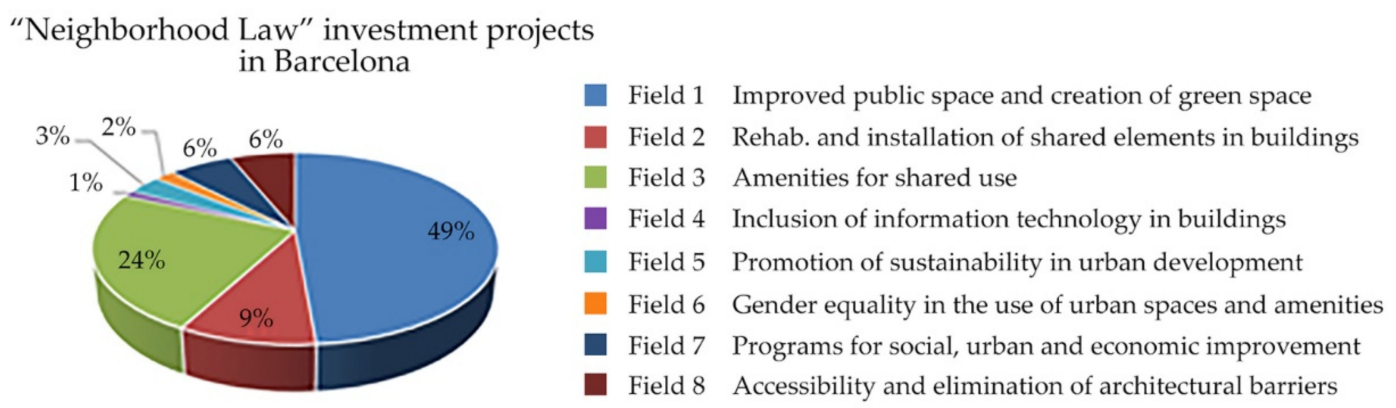

Figure 6. Public investment in Barcelona by type of intervention. 
From 2004 to 2010, twelve neighborhoods in Barcelona began their interventions with a total investment of $€ 222.3$ million and an average of $€ 18.5$ million per neighborhood during the established four-year implementation period. Investments by type of intervention are detailed in Figure 6.

As we can see, most funds-73\%-were invested in public spaces and shared facilities. Just $9 \%$ of public subsidies were spent on the rehabilitation of residential buildings. Furthermore, just $3 \%$ was spent on projects promoting sustainability (Figure 6). In essence, projects were aimed at funding urban deficits tied to urban planning needs, the first of the listed goals. In an economic context, the remaining objectives-of a social, socio-economic, or environmental nature-were seriously underrepresented [46]. Programs for the rehabilitation of urban fabric were designed in keeping with the general plan and each neighborhood's specific needs. The whole of the intervention, with the exception of the building rehabilitation program, is based on a co-financing in equal parts between the autonomous and local administration. Work on buildings received a 50\% public subsidy, while the rest had to be paid for by the owners. However, in disadvantaged neighborhoods, the funds earmarked for rehabilitation were rarely exhausted.

A detailed analysis of benefits is quite complex due to a lack of data that are up-to-date or specific to areas within neighborhoods. Moreover, the effects of these interventions are not immediately visible and must be analyzed through the trends generated once the project is completed. Finally, any extraordinary investments realized later on must also be taken into account. As a result, nine variables involving population, income, activity, and urban values were analyzed over a seven-year period once the intervention projects were completed.

The analysis showed that after the completion of the intervention, indicators varied greatly depending on whether neighborhoods were central or outlying (Figure 7). To this end, we established criteria for comparison using citywide averages and control neighborhoods without renewal projects. After the interventions, there was a significant rise in population in both central and outlying neighborhoods, and a loss of population in outlying neighborhoods where no intervention took place. There was also a significant drop in the number of residents 75 years or older in central neighborhoods that underwent urban renewal projects. There was a general growth of the immigrant population in outlying neighborhoods-particularly pronounced in neighborhoods where interventions took place.

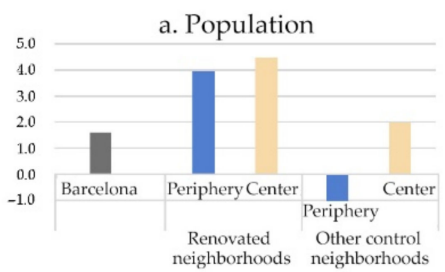

d. Income index for local population
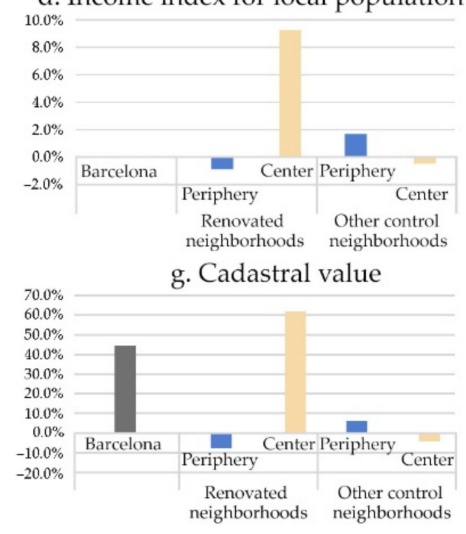

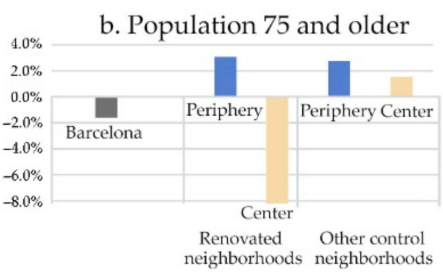

e. Reduction of unemployment

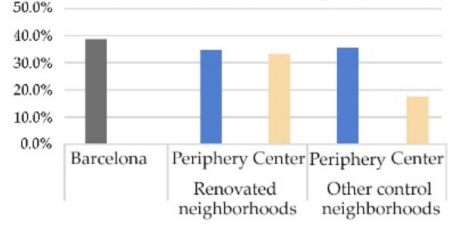

h. Average value of used housing, $€ / \mathrm{m}^{2}$

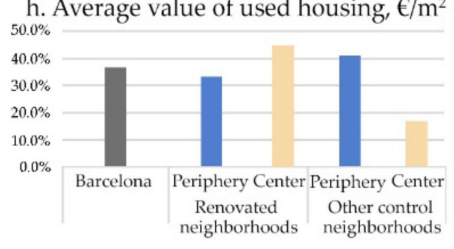

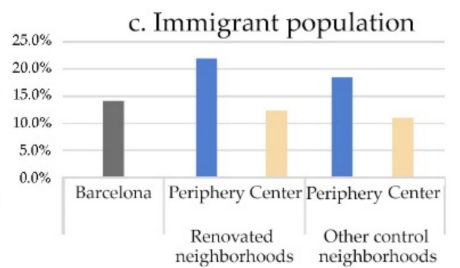

f. Low levels of educational attainment

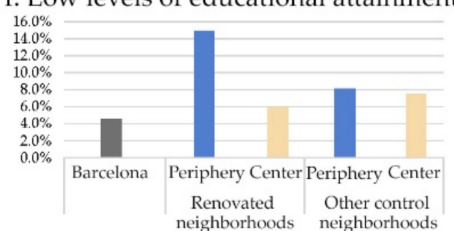

i. Average rental value, $€ / \mathrm{m}^{2}$

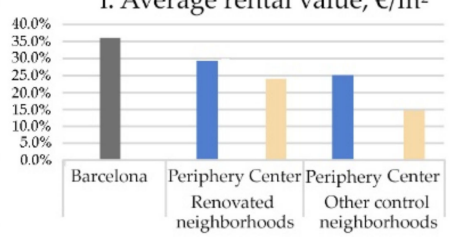

Figure 7. Evolution of population, income, and urban values, 2013-2019. Source: created by the author using data from the Department of Statistics of the Barcelona City Council. 
A rise in income after interventions in central neighborhoods show that the rising population is due to the arrival of social classes with greater purchasing power. Meanwhile, immigrants moved to outlying neighborhoods that had undergone urban renewal projects, and these areas experienced a $0.8 \%$ drop in income. No difference in unemployment figures was observed between the outlying neighborhoods that had and had not undergone urban renewal projects, although there was a drop in unemployment in the central neighborhoods that had. In general, urban renewal efforts in central neighborhoods seem mostly to increase the value of commercial spaces, offices, and amenities. Valuation lists include variations in these values for the city. Values related to residential spaces vary widely. While residential values rose significantly in central neighborhoods that underwent urban renewal projects, they dropped in outlying areas. In both cases, rents rose in comparison to the citywide average.

In summary, indicators rose more in central neighborhoods than in outlying areas. Older residents and those with less purchasing power were driven out of central neighborhoods (gentrification), while a rise in urban values mostly benefitted commercial spaces and non-residential activities. All urban renewal projects attracted new residents.

\subsection{Barcelona's "Neighborhood Plan"}

Barcelona's Pla de barris or "Neighborhood Plan" [6] was executed from 2016 to 2020, with an investment of $€ 150$ million provided entirely by the City Council. This was an emergency plan designed to intervene in the city's 16 most disadvantaged neighborhoods (Figure 8), particularly those along the Besòs River. A second phase is planned to extend the project until 2024.
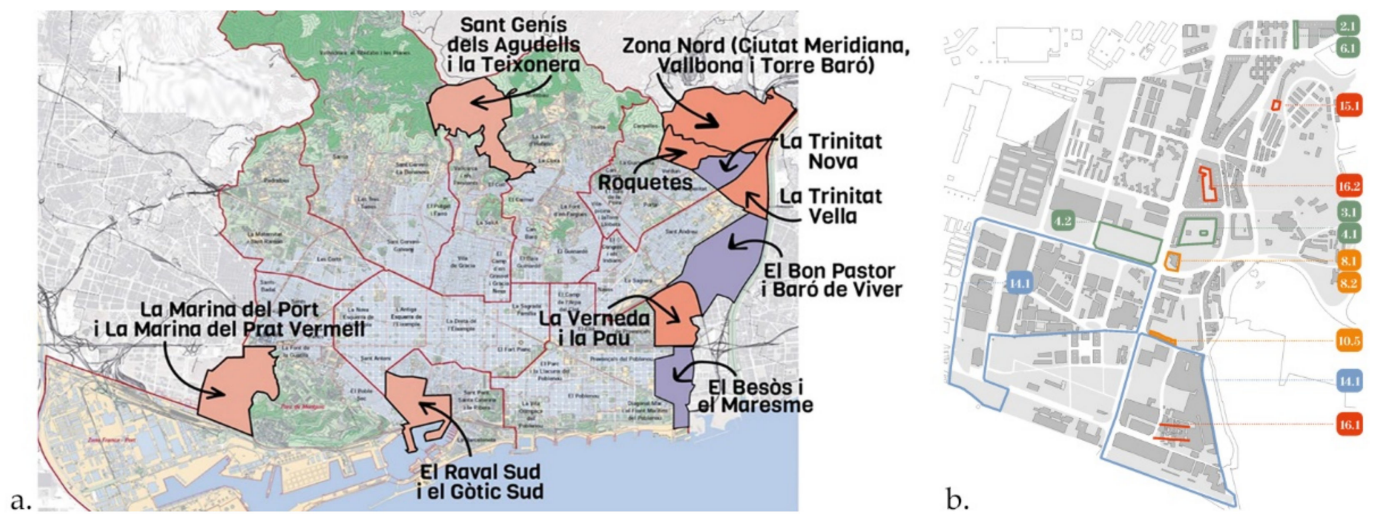

Figure 8. (a) Areas included in Barcelona's Neighborhood Plan. (b) Detailed map of interventions in the Marina del Port neighborhood. Source: Foment Ciutat [6].

This plan is designed to meet the individual needs of neighborhoods highlighted in a series of detailed studies analyzing a wide range of issues. As stated in the text of the Neighborhood Plan, it seeks initiatives that address a range of issues, collaboration among different administrations, the empowerment of residents, and a commitment to evaluation and accountability [47]. It seeks to benefit residents and places programs for social cohesion and citizen participation first. Investment is divided into four main areas:

- Social rights;

- Education;

- Economic activity;

- Urban ecology.

This plan addressed the lack of adequate amenities and public spaces denounced by residents, but it also included a series of programs directly aimed at assisting the local population. The budget allotted to these programs was a relatively small portion of the whole, but they focused on training, employment, health, citizen participation, and community action. Soft technologies require much less investment than other initiatives and are more sustainable. This type of investment model creates a system for rehabilitating 
the residential fabric based on the singularities of each vulnerable neighborhood. In lowincome areas building maintenance is generally insufficient, yet administrative orders to restore these buildings are accompanied with coercive fines. Urban planning laws place the onus of maintaining buildings on the owner. In cases of insufficient maintenance, a corrective administrative procedure is initiated. Once municipal authorities take note of the insufficiency, they inform the owner with an administrative order calling on them to complete the necessary work. Should the owner fail to do so, they are subjected to coercive fines that can be issued multiple times if the work is not done. Since these homeowners lack the resources to pay for either the work or the fines, the buildings are never restored: this system is nothing but a dead end for disadvantaged communities of homeowners. As a result, a program was designed using in-depth knowledge of the local residential fabric, and it included an action plan and a management model that make the renovation of this type of buildings possible.

Detailed knowledge of the affected area is fundamental when designing any sort of urban intervention. This program started with an in-depth study $[48,49]$, based on the sources of data available to the public administration with the goal of detecting areas of residential vulnerability. Areas were characterized using a broad range of indicators related to urban and socioeconomic weaknesses. This was used as a basis for a second field study $[50,51]$ on the detected weaknesses and their relationship to the state of repair of buildings and the social particularities of residents. This provided detailed knowledge on which buildings required urgent intervention (Figure 9).

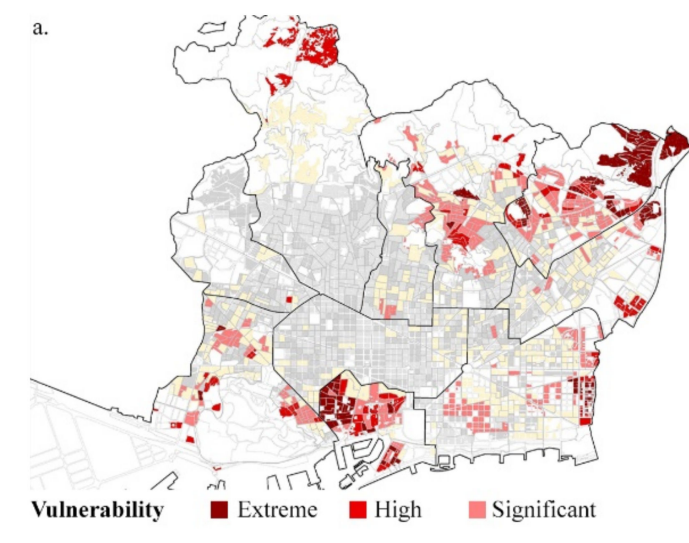

Figure 9. (a) Map of vulnerability in Barcelona as a whole. Source: Adapted from $[48,50]$.

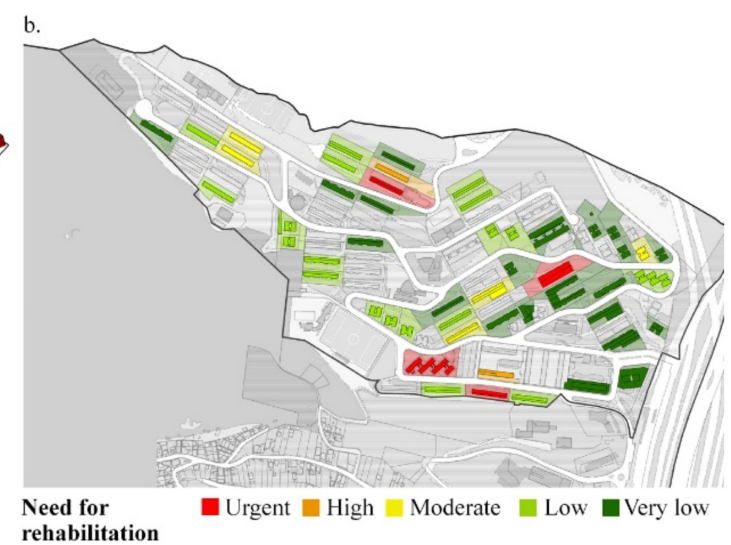

(b) Pre-diagnostic map of the Ciutat Meridiana neighborhood.

This rehabilitation model was applied in the Programa per a finques d'alta complexitat, or "Program for High-Complexity Buildings" [52]. The program focused on reaching accords as the best way of managing the process, and saw subsidiarity as a way of addressing homeowners' unfamiliarity with bureaucratic processes. Management teams contacted the identified communities and offered them a support plan. An initial accord between the administration and groups of homeowners allowed for more detailed studies of the socioeconomic characteristics of the community and the work required by the building. A second accord was then reached on projects, costs, and public subsidies. At the same time, since communities often lacked coordination, officials helped them organize decisionmaking bodies as a way of empowering them and allowing them to take responsibility for building maintenance in the future.

This program is still ongoing. It is currently working with the 404 buildings found to be in urgent need of rehabilitation that have owners in precarious socioeconomic conditions. This model seems to be succeeding in the rehabilitation of nearly all the buildings in question, and it also seems to be well-received by residents. However, it is still too early to have a full idea of its repercussions. 


\section{Conclusions}

In Barcelona, experiences with rehabilitation programs have shown that the results are more positive when plans are designed for specific areas of the city. One example is the creation of Preferential Action Sectors in Ciutat Vella in the late 1990s, which tripled rehabilitation activity. More recently, the Program for High-Complexity Buildings has launched the renovation of particularly vulnerable areas-buildings that were previously seen as hopeless. Nevertheless, some of the general rehabilitation program's strategic initiatives were indeed successful: one example is the plan for the installation of elevators, which has had a significant impact.

The funds invested in rehabilitation programs and the size of portions allotted to different purposes provide some very interesting data. The rehabilitation of residential buildings makes up more and more of the total investment (Table 3). Public subsidies are on the rise and work is increasingly focused on underprivileged areas; as a result, private investment has decreased. Public policies in Barcelona are increasingly aimed at vulnerable urban settings.

Table 3. Public investment: in total and in private rehabilitation initiatives. Data provided in millions of euros.

\begin{tabular}{cccccc}
\hline Program & Period & Total Investment & $\begin{array}{c}\text { Investment in } \\
\text { Rehabilitation }\end{array}$ & $\begin{array}{c}\text { Private Contributions } \\
\text { to Rehabilitation }\end{array}$ \\
\hline Rehabilitation Program & $2010-2018$ & - & 308.8 & - & $67 \%$ \\
Ciutat Vella ARI & $1988-2002$ & 1241 & 32.9 & $2.7 \%$ & $70 \%$ \\
Neighborhood programs & $2004-2010$ & 222 & 8.5 & $3.8 \%$ & $50 \%$ \\
Neighborhood Plan & $2016-$ present & 110 & 18 & $16 \%$ & $25 \%$ \\
\hline
\end{tabular}

The general rehabilitation program was launched in 1988 and is still active. The data provided here are taken from the study of the 2010-2018 period.

When interventions were designed for specific neighborhoods or areas, rehabilitation programs continued to improve and work increasingly in coordination with other initiatives. The city's general rehabilitation program has a different focus, and does not interact directly with other initiatives; however, when granting subsidies, it does take into account how residences are used. This model will need to take on new challenges [35] regarding the complexity of management, taxation, and its potentially counterproductive effects on lower-income families. Subsidies sometimes lead to disadvantaged families losing social aid, as these subsidies are seen as an additional source of income.

Regarding program management, from a strictly functional point of view, there has been a move towards fundamental structures that serve citizens. The paperwork required to obtain public subsidies continues to be excessive, but the sheer abundance of administrative regulations make this difficult to solve. Navigating these processes requires a level of skill that excludes underprivileged areas, either because of residents' lack of economic resources or their lack of management abilities. It seems clear that future management models need to be greatly improved, although The Neighborhood Plan has had some success in addressing this issue by placing the onus on specialized teams.

The Neighborhood Plan seriously addresses citizen disaffection in the rehabilitation of residential buildings, from a clear commitment to organizing the communities of owners and assuming the administrative procedures. The managerial burden that the relationship with the administration entails is transferred to the entity that develops the program.

The effort in management and the economic cost is higher; however, it is found that it helps to close the gap in the citizenship-administration relationship.

As for the benefits obtained, it is clear that not all public investments have positive results. Two critical areas must be addressed: deeper analyses are needed to ensure more efficient interventions, and adequate models for intervention and funding must be available.

Although Barcelona's historic city center was saved, the interventions in Ciutat Vella have had unwanted effects on how the resulting capital gains were channeled. Uncontrolled intervention in the real estate market produced serious gentrification effects and distortions 
in the sale and rental value of homes. Neighborhood programs provided vastly different results depending on whether they were applied in central or outlying areas; this shows that different models that take into account the particularities of each location are needed.

With detailed prior knowledge of an area, efficient programs can indeed be created, but they must also include monitoring that goes beyond management indicators. That way, the unwanted side effects of urban transformation can be corrected in time.

Public rehabilitation programs are increasingly disruptive and are focused more and more on taking advantage of public resources. In addition to generating significant improvements in quality of life and the urban environment, they can also improve social cohesion and correct social deficits. We have looked at these developments by comparing the neighborhood programs applied in Barcelona from 2004 to 2010 with the current Neighborhood Plan.

The complexity of the management and governance processes of the programs presented, allow a greater analysis of the aspects of success. However, the study carried out, in its context, provides transferable and practical guidelines for research and program design. Thus, the governance process, the detailed knowledge of the territory and the monitoring of the programs, are outlined as key elements in the design of public intervention.

In Barcelona, perhaps because of the pleasant climate, energy efficiency has played a very minor role in building rehabilitation. Out of either ignorance or a lack of funds, homeowners have not seen this as important. When it comes to improving energy efficiency, both the culture and a lack of encouragement have played a role. The limited experience of public programs in this area has also reduced their effectiveness. It is important to address the installation of efficient energy-generating systems as well as the improvement of building insulation-even if we do so in the context of a Mediterranean climate.

We hope we have shown that success depends not only on the kind intentions of those designing urban renewal programs, but also on the methods and management structures used. In this regard, progress is still being made.

Author Contributions: Conceptualization, A.U. and P.G.-A.; methodology, A.U.; formal analysis, A.U.; investigation, A.U.; resources, A.U.; data curation, A.U.; writing-original draft preparation, C.C. and A.U.; writing-review and editing, C.C. and S.V.-G.; visualization, S.V.-G.; supervision, P.G.-A.; project administration, P.G.-A.; funding acquisition, P.G.-A. All authors have read and agreed to the published version of the manuscript.

Funding: This research was funded by the ongoing R\&D project Re-Inhabit. Indicadores socioespaciales para la mejora del stock habitacional en zonas vulnerables. Criterios de actuación en los casos de las áreas metropolitanas de Barcelona y Bilbao. RTI 2018-101342-BI00, supported and funded by the Spanish Ministry of Science and Innovation.

Institutional Review Board Statement: Not applicable.

Informed Consent Statement: Not applicable.

Data Availability Statement: Publicly available datasets were analyzed in this study. This data can be found here: http:/ / www.bcn.cat/estadistica/catala/index.htm (accessed on 4 March 2021). Also, data presented in this study are available on request from the corresponding author. The data are not publicly available as are part of unpublished documents.

Conflicts of Interest: The authors declare no conflict of interest.

\section{References}

1. European Commission. Europe's Moment: Repair and Prepare for the Next Generation; European Commission: Bruxelles, Belgium, 2020; Available online: https://ec.europa.eu/commission/presscorner/detail/en/ip_20_940 (accessed on 2 February 2021).

2. Ajuts a la Rehabilitació D'edificis per a Comunitats. Available online: https://habitatge.barcelona/ca/serveis-ajuts/rehabilitacio/ ajuts / edificis-comunitats (accessed on 7 February 2021).

3. Project Ciutat Vella: Revitalization of the Historical Center of Barcelona, Spain. Available online: http://habitat.aq.upm.es/bpes/ onu98/bp443.en.html (accessed on 7 February 2021).

4. Fiori, M. (Ed.) Transformación urbana y estructura residencial en el centro histórico de Barcelona. In ReVivir el Centro Histórico. Barcelona, La Habana, Ciudad de México y Quito; UOC: Barcelona, Spain, 2013. 
5. Cremades, E. Plans d'Intervenció Integral de Barcelona. Barc. Soc. 2011, 19, 5-16. Available online: https:/ /ajuntament.barcelona.cat/ dretssocials/sites/default/files/revista/revista-19-art0-plans-intervencio-integral-barcelona.pdf (accessed on 6 February 2021).

6. El Pla de Barris de Barcelona. Available online: https://pladebarris.barcelona/ca (accessed on 6 February 2021).

7. Osborne, D.; Gaebler, T. La Reinvención del Gobierno. La Influencia del Espíritu Empresarial en el Sector Público; Editorial Paidós: Barcelona, Spain, 1994.

8. Aguilar, L.F. El futuro de la gestión pública y la gobernanza después de la crisis. The future of Public Administration and Governance after the Crisis. Front. Norte 2010, 22, 187-213. Available online: http:/ / www.scielo.org.mx/scielo.php?script=sci_ arttext\&pid=S0187-73722010000100008\&lng=es\&tlng=es (accessed on 27 February 2021).

9. Pont Vidal, J. Modelos innovadores de administración y gestión pública: Hacia la emergencia de nuevos paradigmas. Gestión Análisis Políticas Públicas 2016, 8, 6-26. [CrossRef]

10. Campos-Venuti, G. Urbanismo y Austeridad; Siglo Veintiuno de España Editores: Madrid, Spain, 1981.

11. Sennett, R. Construir y Habitar. Ética Para la Ciudad; Editorial Anagrama: Barcelona, Spain, 2019.

12. Barreto-Nieto, L.; Cerón-Rincón, L.; Fernández-Medina, A. Metodologías para la investigación en políticas públicas. In Enfoques para el Análisis de Políticas Públicas; André-Noél, R.D., Ed.; Bogotá-UNAL: Bogota, Columbia, 2010.

13. Cáritas España. Las Personas en Situación de sin Hogar Acompañadas por Cáritas. Contexto en 2019 y Durante el Estado de Alarma y la COVID-19; Cáritas Española Editores: Madrid, Spain, 2020; Available online: https:/ / caritas-web.s3.amazonaws.com/mainfiles/uploads/2020/10/C\%C3\%81RITASestudios-e-investigaciones-22-web-.pdf (accessed on 27 February 2021).

14. Eurostat. Statistics Explained. Estadísticas Sobre Vivienda. Available online: https://ec.europa.eu/eurostat/statistics-explained/ index.php?title=Housing_statistics/es (accessed on 27 February 2021).

15. Available online: https://habitatge.barcelona/sites/default/files/questions_dhabitatge_20.pdf (accessed on 27 February 2021).

16. Rolnik, R. La Guerra de Los Lugares: La Colonización de la Tierra y la Vivienda en La Era de Las Finanzas; LOM Ediciones: Santiago de Chile, Chile, 2019.

17. Departament d'Estadística i Difusió de Dades. Oficina Municipal de Dades. Ajuntament de Barcelona. Available online: http:/ / www.bcn.cat/estadistica/catala/index.htm (accessed on 27 February 2021).

18. Montaner, J.M.; Álvarez, F.; Muixí, Z. (Eds.) Archivo Crítico Modelo Barcelona 1973-2004; Ajuntament de Barcelona-Departamento de Composición Arquitectónica de la ETSAB-UPC: Barcelona, Spain, 2011.

19. Ajuntament de Barcelona. Pla pel Dret a l'Habitatge de Barcelona 2016-2025. Resum Executiu; Ajuntament de Barcelona: Barcelona, Spain, 2016. Available online: https:/ / habitatge.barcelona/sites/default/files/pdhb_-_resum_executiu_versio_accessible_0_0. pdf (accessed on 28 February 2021).

20. Innovation in Affordable Housing. Barcelona 2015-2018. Available online: https:/ /ajuntament.barcelona.cat/barcelonallibres / sites/default/files/publicacions_fitxers/pdf_indexat_innovation_affordable_housing_barcelona_eng.pdf (accessed on 27 February 2021).

21. Porcel, S.; Antón-Alonso, F.; Muñoz, I. Les polítiques de millora de barris: Una introducció. Rev. Pap. 2021, 63, 10-19. Available online: https://iermb.uab.cat/ca/revistapapers/n-63-metropolis-vulnerabilitat-urbana-i-politiques-de-millora-debarris / (accessed on 27 February 2021).

22. Rueda Palenzuela, S. Les superilles per al disseny de noves ciutats i la renovación de les existents. El cas de Barcelona. Rev. Pap. 2017, 59, 78-93. Available online: https:/ /iermb.uab.cat/wp-content/uploads/2017/12/59-7.pdf (accessed on 27 February 2021).

23. Antón-Alonso, F.; Porcel, S.; Cruz, I. La vulnerabilitat urbana a Barcelona: Persistencia, concentració i complexitat. Rev. Pap. 2021, 63, 50-67.

24. Matesanz-Parellada, A.; Hernández-Aja, A. Evolución de los parámetros del enfoque integrado en las políticas urbanas en los barrios vulnerables en España. Gestión Análisis Políticas Públicas 2018, 10, 82-99. [CrossRef]

25. Gobierno de España. Cambio Climático. Mitigación: Políticas y Medidas. Residencial, Comercial e Institucional. Available online: https://www.miteco.gob.es/es/cambio-climatico/temas/mitigacion-politicas-y-medidas/edificacion.aspx (accessed on 7 February 2021).

26. Ministerio de Fomento. Estrategia a Largo Plazo Para la Rehabilitación Energética en el Sector de la Edificación en España en Desarrollo del Artículo 4 de la Directiva 2023/27/UE; Ministerio de Fomento: Madrid, Spain, 2014. Available online: https:/ /www.miteco.gob. es/images/es/rciestrategiarehabilitacion_tcm30-179115.pdf (accessed on 7 February 2021).

27. United Nations. Resolution Adopted by the General Assembly on 25 September 2015; United Nations: New York, NY, USA, 2015; Available online: https://unctad.org/system/files/official-document/ares70d1_en.pdf (accessed on 7 February 2021).

28. Observatorio Vasco de la Vivienda. Políticas de Rehabilitación y Regeneración Urbana en Europa; Observatorio Vasco de la Vivienda: Leioa, Spain, 2010; Available online: https://www.etxebide.euskadi.eus/contenidos/informacion/ovv_administracion129/es_ ovv_admi/adjuntos/Politicas_rehab_reg_urbana_europa_es.pdf (accessed on 7 February 2021).

29. Agencia Estatal. Gobierno de España. Real Decreto 1494/1987, de 4 de Diciembre, Sobe Medidas de Financiación de Actuaciones Protegibles en Materia de Vivienda; Agencia Estatal: Madrid, Spain, 1987; Available online: https://www.boe.es/eli/es/rd/1987/12/04/1494 (accessed on 7 February 2021).

30. Cuchí, A.; de la Puerta, I. Diagnóstico de la Rehabilitación en las Comunidades Autónomas. Luces y Sombras de un Sector que no Despega; Grupo de Trabajo Sobre Rehabilitación (GTR): Madrid, Spain, 2016; Available online: https://www.activatie.org/publicacion?499 (accessed on 7 February 2021). 
31. Diaz, C.; Cornado, C.; Vima-Grau, S. La adición de nuevos ascensores en conjuntos residenciales modernos del Área Metropolitana de Barcelona. In Proceedings of the Euro-American Congress on Construction Pathology, Rehabilitation Technology and Heritage Management, Universidad de Cantabria, Barcelona, Spain, 24 March 2020; pp. 2855-2862.

32. Cornadó, C.; Vima-Grau, S.; Martín, E. Intervenciones de mejora de accesibilidad en los edificios históricos de Barcelona. In Proceedings of the XIII Congreso Internacional Ciudad y Territorio Virtual: Retos y Paradigmas de la Ciudad Contemporánea, Barcelona, Spain, 2-4 October 2019; CPSV: Barcelona, Spain, 2019. [CrossRef]

33. Generalitat de Catalunya, Departament de Territori i Sostenibilitat. Informe Sobre el Sector de L'habitatge a Catalunya. Any 2018; Generalitat de Catalunya: Barcelona, Spain, 2019. Available online: http://habitatge.gencat.cat/web/.content/home/dades/ estadistiques/03_Informe_sobre_el_sector_de_1_habitatge_a_Catalunya/informe_sobre_el_sector_de_lhabitatge_a_catalunya / docs/Informe_2018.pdf (accessed on 7 February 2021).

34. Observatorio Ciudad 3R. Informe de Evaluación Sobre Politicas Públicas de Rehabilitación Residencial en Epaña (2013-2017) Reflexiones sobre el desafío 2020/2030; Rubio del Val, J., Ed.; Ministerio para la Transición Ecológica, Gobierno de España: Zaragoza, Spain, 2019. Available online: https://gbce.es/wp-content/uploads/2019/12/IINFORME-EVALUACIÓN-SOBRE-POLÍTICAS-PÚBLICASDE-REHABILITACION-2013-17.pdf (accessed on 7 February 2021).

35. Cabrera, E. La transformació urbana de la Ciutat Vella: 1988-1998. Barc. Soc. 2002, 9, 14-30. Available online: https://ajuntament. barcelona.cat/dretssocials/sites/default/files/revista/revista9-art2-transformacio-urbana-ciutat-vella-1988-1998.pdf (accessed on 6 February 2021).

36. Sargatal Bataller, M.A. El estudio de la gentrificación. Biblio3w Rev. Bibliográfica Geogr. Cienc. Soc. 2000, 228. Available online: http:/ / www.ub.edu/geocrit/b3w-228.htm (accessed on 8 March 2021).

37. Vilà Bosqued, G. Reforma urbana, mercado de vivienda y cambio social: Los procesos de gentrificación en la ciudad de Barcelona. In Poder, cultura y civilización, Proceedings of the IX Congreso Español de Sociología, Barcelona, Spain, 13-15 September 2007; Federación Española de Sociología in collaboration with Associació Catalana de Sociologia: Brascelona, Spain, 2007.

38. Ter Minassian, H. Le paysage de la gentrification à Barcelone. Strat. Matériaux Rech. Sci. Soc. 2007, 13. [CrossRef]

39. Illa, M. La Falsa Solució Turística: Concentració de Beneficis i Deute Social; Observatori del Deute en la Globalització (ODG): Barcelona, Spain, 2019; Available online: https:/ / odg.cat/wp-content/uploads/2019/02/INFORME-CAT-ONLINE.pdf (accessed on 6 February 2021).

40. Delgado, M. El barraquismo invisible. In Proceedings of the Fórum Barraca Barcelona, Fundación Mies Barcelona, Barcelona, Spain, 20-22 February 2003.

41. Antón-Alonso, F.; Cortés, L.; Martínez, C.; Navarrete, J. Políticas y bienes sociales: Procesos de vulnerabilidad y exclusión social. In La Exclusión Residencial en España VI Informe Sobre Exclusión y Desarrollo Social en España; Fundación FOESSA: New York, NY, USA, 2008; pp. 349-368.

42. Uzqueda, A. Instrumentos para la Recuperación de Plusvalías, en un Modelo Sostenible de Financiación de Políticas Públicas de Rehabilitación, Desde el Análisis de Ciutat Vella, Barcelona. Master's Thesis, Universitat Politècnica de Catalunya, Barcelona, Spain, 2010.

43. Parlament de Catalunya. Llei 2/2004, 4 de Juny, de millora de Barris, Arees Urbanes $i$ Viles Que Requereixen una Atenció Especial; Parlament de Catalunya: Barcelona, Spain, 2004. Available online: https://www.parlament.cat/document/nom/TL45.pdf (accessed on 5 February 2021).

44. Muixí, Z.; Ciocoletto, A. Catalonian Neighbourhood Development law: The gender perspective as a planning tool. In Proceedings of the New Urban Question-Urbanism beyond Neo-Liberalism, 4th International Conference of the International Forum on Urbanism (IFoU), Amsterdam/Delft, The Netherlands, 26 November 2009; pp. 1331-1338. Available online: https://upcommons. upc.edu/bitstream/handle/2117/6728/Catalonian_neighbourhood.pdf (accessed on 7 February 2021).

45. Botell, R. La ley de barrios de Cataluña. Experiencias y resultados de 7 años de aplicación. In Jornadas Valencia: Regeneración Urbana. 2011. Available online: http://www.five.es/descargas/archivos/Regenera/02_Ramon_Botey_LeyBarrios_Catalunya. pdf (accessed on 7 February 2021).

46. Piasek, G.; Vima-Grau, S.; García-Almirall, P. Tendencias y omisiones de las políticas de rehabilitación urbana. Lo que la política no mira, no existe? In Proceedings of the IV Congreso ISUF-H, Barcelona, Spain, 28-30 September 2020; Available online: https: / / upcommons.upc.edu/bitstream/handle/2117/328580/tema_2_codcom_377_codcot_331.pdf?sequence=1\&isAllowed=y (accessed on 7 February 2021).

47. Muñoz, F. La regeneración de la ciudad en Europa: Nuevas problemáticas, nuevos actores, nuevas políticas. In Transformar la Ciudad con la Ciudadanía. Criterios y Reflexiones para el Plan de Barrios de Barcelona; Nello, O., Ed.; Ajuntament de Barcelona, Foment de Ciutat, S.A.: Barcelona, Spain, 2017; pp. 33-39. Available online: https://media-edg.barcelona.cat/wp-content/uploads/2017 /03/22180511/Transformar-la-ciudad-370-1217.pdf (accessed on 7 February 2021).

48. Garcia-Almirall, P.; Vila, G.; Vima-Grau, S.; Uzqueda, A. Estudi i Detecció a la Ciutat de Barcelona D’àmbits de Vulnerabilitat Resi-dencial. Ajuntament de Barcelona; Universitat Politècnica de Catalunya: Barcelona, Spain, 2017.

49. Cornadó, C.; Garcia-Almirall, P.; Vima-Grau, S.; Vila, G.; Uzqueda, A. Methodology for the detection of residential vulnerable areas-The case of Barcelona. IOP Conf. Ser. Mater. Sci. Eng. 2017, 245. [CrossRef]

50. Cornadó, C.; Garcia-Almirall, P.; Vima-Grau, S. Prediagnosi de L'edificació Residencial en Els Ambits de Vulnerabilitat de la Ciutat de Barcelona. Ajunt. Barc. 2017, 1-91. 
51. Cornadó, C.; Vima-Grau, S.; Garcia-Almirall, P. Pre-diagnosis Protocol for Large Residential Building Stock. The Case of Barcelona's Vulnerable Areas. In Hygrothermal Behaviour and Building Pathologies. Building Pathology and Rehabilitation; Delgado, J., Ed.; Springer: New York, NY, USA, 2021; Volume 14. [CrossRef]

52. Ajuts a la Rehabilitació per a Finques d'alta Complexitat. Available online: https://habitatge.barcelona/ca/serveis-ajuts/ rehabilitacio/ajuts/finques-alta-complexitat (accessed on 7 February 2021). 